\title{
Implementasi Penjadwalan Round Robin pada Task Scheduler untuk Pembaruan Aplikasi Otomatis
}

\author{
Iqbal Fikri Al-Hadi ${ }^{1, *}$, Safrinadi Ilham ${ }^{2}$, Choirunnufatul Chusna ${ }^{3}$, Abd. Charis Fauzan ${ }^{4}$ \\ Program Studi Ilmu Komputer, Universitas Nahdhatul Ulama Blitar, Indonesia \\ 1iqbalfikri999@gmail.com*, ${ }^{2}$ safrinadiilham@gmail.com, ${ }^{3}$ chusnaanaufaa@gmail.com, ${ }^{4}$ abdcharis@ unublitar.ac.id \\ *corresponding author
}

ARTIKEL INFO

Article history

Diterima: 3 Juni 2019

Direvisi: 30 Juli 2019

Diterbitkan: 30 Agustus 2019

Keywords

Task scheduler

Aplikasi

Round robin

Burst time

Waiting time

\section{ABSTRAK}

Permasalahan pada penelitian ini adalah ketidakteraturan beberapa aplikasi yang ada di komputer dan sejenisnya dalam melakukan pembaruan, sehingga mengakibatkan tidak meratanya beberapa aplikasi dalam melakukan pembaruan (update). Subjek penelitian ini adalah aplikasi yang termuat di komputer /laptop diinputkan dalam sebuah aplikasi penjadwalan, dengan menggunakan aplikasi penjadwalan bawaan windows yaitu, task scheduler. Round Robin adalah algoritma tertua, dan paling sering digunakan dalam proses CPU, cara kerja Round Robin ini sendiri adalah membuat pergiliran antrian proses, proses akan mendapatkan alokasi quantum time. Apabila quantum time telah habis maka secara otomatis akan berganti ke proses lainnya. Hasil penelitian menunjukkan bahwa terdapat pengaruh yang positif dan signifikan dalam meningkatkan efisiensi waktu dalam melakukan pembaruan secara otomatis.

\section{PENDAHULUAN}

Penjadwalan adalah suatu mekanisme di sistem operasi yang berkaitan dengan urutan kerja yang dilakukan sistem komputer. Penjadwalan bertugas memutuskan proses yang harus berjalan, kapan, dan selama berapa lama proses berjalan. Terdapat beberapa aplikasi yang mendukung proses penjadwalan, salah satunya adalah task scheduler, system scheduler, task till down. Pada penelitian ini dibahas tentang task scheduler [1]. Task scheduler merupakan aplikasi bawaan dari windows yang berfungsi sebagai aplikasi penjadwalan. Task scheduler bisa digunakan untuk menjalankan program, mengirim email, dan notifikasi pesan dari task scheduler. Tetapi untuk mengirim pesan otomatis jarang digunakan. Task scheduler adalah komponen dari Microsoft Windows yang menyediakan kemampuan untuk menjadwalkan menjalankan program atau script pada waktu yang telah ditentukan atau setelah interval waktu tertentu [2].

\section{METODE}

Metode adalah teknik yang digunakan untuk memecahkan suatu masalah dan memberikan hasil sesuai dengan yang diharapkan. Peneliti menggunakan sumber dari buku, jurnal, dan sumber-sumber lain yang terpercaya untuk digunakan dalam penelitian ini. Penelitian ini berkaitan dengan sistem operasi dan algoritma penjadwalan proses. Dan yang akan peneliti bahas pada jurnal kali ini adalah metode penjadwalan proses pembaharuan aplikasi menggunakan aplikasi task scheduler yang merupakan komponen dari microsoft windows [3]. 


\section{Task Scheduler}

Task scheduler adalah komponen dari Microsoft Windows yang menyediakan kemampuan untuk menjadwalkan program atau script pada waktu yang telah ditentukan atau setelah waktu interval tertentu. Scheduler task berjalan setiap kali menjalankan windows dan menjalankan latar belakang, dan menjalankan setiap tugas yang telah dijadwalkan pada waktu menentukannya saat membuat tugas [4]. Dengan aplikasi task scheduler ini, pengguna bisa membuat jadwal aktifitas sehari-hari dan juga dapat mengaktifkan alarm agar pengguna ingat dengan jadwal. Selain bisa menjadwalkan program yang bisa menjadwalkan program yang bisa kita jalankan setiap hari, program ini juga bisa mengirim e-mail secara otomatis. Program ini juga bisa mematikan komputer pada waktu yang telah ditentukan dan juga membuat pesan pengingat sehingga sekarang tidak lagi melewatkan tugas yang penting [5].

\section{Round Robin}

Round robin merupakan suatu metode yang cara kerjanya berupa penjadwalan yang membagi setiap proses menjadi porsi waktu yang sama. Proses yang mempunyai waktu proses terpendek akan lebih cepat selesai, daripada proses yang mempunyai waktu proses yang lama. Metode ini akan membuat setiap proses memperoleh jatah waktu didalam quantum waktu yang sama dari tiap-tiap prosesnya dan telah diatur dalam task scheduler [6]. Semua proses tidak ada yang diprioritaskan dan diberi waktu pemrosesan berupa quantum time atau time-slice di dalam proses itu berjalan. Apabila quantum time atau timeslice tadi belum habis dan menunggu selesainya operasi input/output, maka proses tersebut akan diblok dan dialihkan ke proses lain [7]. Round robin dibuat sedemikian rupa untuk memenuhi kebutuhan time-sharing, time sharing berguna untuk berguna untuk meningkatkan waktu respon, dalam proses pembaruan. Waiting time pada Round robin tidak optimal, namun waktu respon pembaruan rata-rata lebih baik [8].

\section{PEMBAHASAN}

Berdasarkan metodeyang dijabarkan, bahwa metode Round Robin tidak memprioritaskan proses yang ada melainkan pembagian waktu yang sama dengan menggilir proses antrian sehingga didapatkan sebuah time quantum, time quantum adalah proses yang dibatasi waktu prosesnya. Apabila time quantum telah selesai atau habis maka pengalokasian akan berpindah ke proses berikutnya oleh CPU.

Tabel 1. Penjadwalan Round Robin

\begin{tabular}{|c|c|c|c|c|c|c|c|c|}
\hline \multicolumn{8}{|c|}{ Algorigtma Penjadwalan Round Robin } & \multirow[b]{2}{*}{$\begin{array}{l}\text { turn around time } \\
\text { (Menit) }\end{array}$} \\
\hline No & Proses & Waktu datang & Burst Time(Jam) & $\begin{array}{c}\text { Waktu } \\
\text { Penjadwalan }\end{array}$ & Waktu mulai & waktu selesai & $\begin{array}{c}\text { waktu } \\
\text { tunggu(Jam) }\end{array}$ & \\
\hline 2 & Opera Update & 2:05:00 & 2 & 2:00:00 & $2: 00: 00$ & 4:00:00 & 0 & 120 \\
\hline 3 & ByteFence Update & $2: 10: 00$ & 2 & $13: 00: 00$ & 13:00:00 & 15:00:00 & 0 & 120 \\
\hline 4 & Adobe Update & $2: 15: 00$ & 3 & $15: 00: 00$ & $15: 00: 00$ & $22: 00: 00$ & 4 & 180 \\
\hline 6 & Mozila Firefox Update & $2: 25: 00$ & 1 & $8: 00: 00$ & $8: 00: 00$ & 9:00:00 & 0 & 60 \\
\hline 7 & $\begin{array}{l}\text { Tencent Gaming Buddy } \\
\text { Update }\end{array}$ & $2: 30: 00$ & 2 & $17: 00: 00$ & $18: 00: 00$ & $19: 00: 00$ & 1 & 120 \\
\hline 8 & Aimp Update & $2: 35: 00$ & 1 & $18: 00: 00$ & 20:00:00 & $20: 00: 00$ & 2 & 60 \\
\hline 9 & IDM Update & $2: 40: 00$ & 1 & 20:00:00 & 20:00:00 & 21:00:00 & 0 & 60 \\
\hline
\end{tabular}

Sebagaimana ditunjukkan pada Tabel 1, penulis menggunakan beberapa data input, antara lain:

1. Waktu datang, merupakan waktu awal aplikasi di jadwalkan 
2. Burst time merupakan alokasi lama waktu eksekusi yang telah di alokasikan kepada masing-masing proses sejak proses itu dibuat. Waktu aplikasi berjalan (accessed)

3. Waktu mulai merupakan waktu perjalanan aplikasi (waktu awal update aplikasi)

4. Waktu selesai merupakan waktu menunggu update dari aplikasi sebelumnya

5. Turn arround time merupakan total waktu aplikasi berjalan

6. Quantum time adalah batasan waktu proses satu ke proses yang lain.

Tabel 1 merupakan hasil dari berbagai aplikasi yang akan diperbarui dan diurutkan prioritasnya berdasarkan waktu mulai pembaruan, daftar aplikasi yang akan diperbarui memulai penjadwalan berdasarkan waktu datang atau aplikasi mulai dijadwalkan. Aplikasi mulai diperbarui otomatis pada 2 jam sekali atau disebut quantum time.

Tabel 2. Eksekusi proses penjadwalan pembaruan aplikasi

\begin{tabular}{|c|c|c|c|c|c|c|c|c|c|c|c|c|c|c|c|c|c|c|c|c|c|c|c|c|}
\hline \multirow{2}{*}{ proses } & \multicolumn{24}{|c|}{ Jam Berjalan } \\
\hline & 1 & 2 & 3 & 4 & 5 & 6 & 7 & 8 & 9 & 10 & 11 & 12 & 13 & 14 & 15 & 16 & 17 & 18 & 19 & 20 & 21 & 22 & 23 & 24 \\
\hline Avast anti virus Upc & & & & & & & & & & & & & & & & & & & & & & & & \\
\hline Opera Update & & & & & & & & & & & & & & & & & & & & & & & & \\
\hline ByteFence & & & & & & & & & & & & & & & & & & & & & & & & \\
\hline Adobe Update & & & & & & & & & & & & & & & & & & & & & & & & \\
\hline Crome Update & & & & & & & & & & & & & & & & & & & & & & & & \\
\hline Mozila Firefox Upda & & & & & & & & & & & & & & & & & & & & & & & & \\
\hline $\begin{array}{l}\text { Tencent Gaming Bu } \\
\text { Update }\end{array}$ & & & & & & & & & & & & & & & & & & & & & & & & \\
\hline Aimp Update & & & & & & & & & & & & & & & & & & & & & & & & \\
\hline IDM Update & & & & & & & & & & & & & & & & & & & & & & & & \\
\hline CorelDraw Update & & & & & & & & & & & & & & & & & & & & & & & & \\
\hline
\end{tabular}

Sebagaimana Tabel 2, pada setiap kelas mempunyai prioritas-prioritas dari sebuah himpunan. Akan tetapi penjadwalan akan diubah dari kelas prioritas rinci menjadi kelas prioritas umum, kemudian dipilih urutan lebih dulu penjadwalannya. Urutan tersebut akan secara otomatis terjeda apabila melebihi batas quantum time. Penjadwalan Round Robin qиеие akan berjalan apabila ditemukan urutan prioritas yang sama.

\section{KESIMPULAN}

Scheduling atau biasa disebut penjadwalan adalah kumpulan mekanisme dan kebijaksanaan yang berkaitan dengan urutan task atau kerja pada sistem komputer. Salah satu metode dalam penjadwalan yang sering digunakan adalah Round robin. Penjadwalan Round robin juga terdapat pada task manager. Task scheduler adalah aplikasi bawaan dari windows yang berguna dalam mengatur waktu pembaruan yang ada di dalam komputer. Aplikasi yang ada akan diproses didalam task Scheduler dan diatur penjadwalannya menggunakan Penjadwalan Round robin tersebut.

\section{REFERENSI}

[1] Durgesh Raghuvanshi. 2018. "Memory Management in Operating System.” International Journal of Trend in Scientific Research and Development 2 (5): 2346-47. http://www.ijtsrd.com/computerscience/operating-system/18342/memory-management-in-operating-system/durgeshraghuvanshi\%0Ahttp://www.ijtsrd.com/papers/ijtsrd18342.pdf.

[2] SAPUTRO, TAN HANDOKO DHARMA. 2013. "Pemodelan CPU Scheduling Dengan Algoritma Round Robin Sebagai Media Pembelajaran Mata Kuliah Sistem Operasi," 1-8.

[3] Lumbantoruan, Gortap. 2016. "Modifikasi Algoritma Round Robin Dengan Dynamic Quantum Time Dan Pengurutan Proses Secara Ascending.” Jurnal ISD 2, No.2 (ISSN:2528-5114): 44-55.

[4] Simamora, Florensius Tri Putra, Widhi Yahya, and Sabriansyah Rizqika Akbar. 2018. "Implementasi Alokasi Memori Dinamis Pada Sistem Komputer Berbasis Clustering K-Means.” Jurnal Pengembangan Teknologi Informasi Dan Ilmu Komputer 2 (1): 11-20. http://j-ptiik.ub.ac.id.

[5] Stallings, William. 2009. COMPUTER ORGANIZATION AND ARCHITECTURE DESIGNING FOR 


\section{PERFORMANCE}

[6] P. Yogie Ariyanto, Soetam Rizky Wicaksono, Jurusan Sistem Informasi, Fakultas Sains, Universitas Ma Chung, J1 Villa, and Puncak Tidar. 2017. "Pengemudi Dengan Menggunakan Algoritma Round Robin ( Studi Kasus : Zena Travel ).” Sanis Dan Teknologi 6 (1): 189-98.

[7] Modus, Penerapan, Pengalamatan Dan, Ardi Panjaitan, and Masdiana Sagala. 2018. "OPERASI ARITMATIKA PADA MIKROPROSESOR” 03: 144-51.

[8] Diarjo, Andi Anto, and Dadang Iskandar Mulyana. 2017. "Penerapan Algoritma Round Robin Dan Modulo Pada Load Balancing." Penerapan Algoritma Round Robin Dan Modulo Pada Load Balancing Web Server 10 (1): 21-34. 